\title{
J.C. Steyn
}

\section{DIE AFRIKAANS VAN DIE BYBELVERTALING VAN $1933^{1}$}

\author{
THE AFRIKAANS OF THE BIBLE TRANSLATION OF 1933
}

\begin{abstract}
The first translators of the Bible had to start their work before the standardisation of Afrikaans. This article firstly explores the difficulties encountered by the Bible translators in breaking with the language of the Statenbijbel. Secondly, it is indicated how translators were able to utilise the insights of linguists and language practitioners who were in the process of standardising the Afrikaans language. The article explores difficulties encountered by the 1933 translators regarding vocabulary, pronouns, verbs and adjectives. From the translations it is clear that by 1922 the Afrikaans is/was/wees already fell into disuse regarding verbs referring to movement and the changing of state. Not one of the translators considered the imperfect seriously; only in the 1933 translation was the historical present tense used in a stylistically satisfactory manner. The plurals of adjectives in a substantive function, and the negative imperative, were not used consistently in the 1933 translation.
\end{abstract}

\section{INLEIDING}

Die eerste Bybelvertalers moes hul werk begin voordat Afrikaans heeltemal gestandaardiseer was. Selfs nog in die eerste dekade van die twintigste eeu het voorstanders van Afrikaans as kultuurtaal gemeen dat 'n Bybelvertaling moes wag solank Afrikaans nog "in die maak" was (Nienaber 1934:58). Bowendien was sowel die Bybellesers as die Bybelvertalers goed bekend met die Nederlandse Statenbijbel, wat eeue lank deur Afrikaanstaliges gelees is. Een van die eindvertalers van die 1933-vertaling, B.B. Keet, het betoog dat "die

$1 \quad$ Die verskyning van die Afrikaanse Bybelvertaling van 1933 is in Augustus 2008 op verskeie maniere herdenk, onder meer met die publikasie van Die Bybel 1933/53-vertaling. Verder het die Bybelgenootskap van Suid-Afrika 'n Bybelfeesviering in Bloemfontein gereël wat begin het met 'n konferensie in samewerking met die Fakulteit Teologie van die Universiteit van die Vrystaat. Verskeie aspekte van die 1933-vertaling is bespreek. Hierdie stuk is 'n verwerking van 'n voordrag oor die Afrikaans van die 1933-vertaling.

Prof. J.C. Steyn, Departement Afrikaans en Nederlands, Duits en Frans, Universiteit van die Vrystaat, Posbus 339, Bloemfontein 9300. E-pos: steynjaap@mweb. 
stroefheid en stramheid wat ongetwyfeld op baie plekke [in die 1933-vertaling] te bespeur is" alleen toegeskryf kan word aan die oorspronklike opdrag aan die vertalers, naamlik "om die model van die Statevertaling te volg". Die inhoud van die Statenbijbel het "diep in die geheue van die vertalers vasgesit", sodat hulle moeite gehad het om af te wyk van die vorm waarin dit verskyn het (Keet 1951:117).

Die outeur se oogmerk met hierdie bydrae is ten eerste om te toon hoe moeilik dit vir die Bybelvertalers was om hulle te ontworstel aan die Statenbijbeltaal, wat selfs in Nederland gou "een min of meer ouderwetsch of archaïstisch tintje" (Verdam \& Stoet 1923:230) gekry het, maar in daardie land die waarde daarvan en ontsag daarvoor eerder vergroot as verminder het. Ten tweede word gelet op die wyse waarop die vertalers gebruik kon maak van die insigte van taalkundiges en taalpraktisyns wat met die standaardiseringsproses van Afrikaans besig was.

Omdat die 1933-vertaling vergelyk word met die vertalings wat dit voorafgegaan het, word eers 'n oorsig dáárvan gegee. Dit is die Statenbijbel, die vertalings van S.J. du Toit en die proefvertaling van 1922.

\section{VORIGE VERTALINGS}

\subsection{Statenbijbel}

Die eerste Nederlandse Bybelvertalings het die weg gebaan vir die Statenbijbel en die opbou van 'n standaardtaal. Die vertalers wou immers soveel mense as moontlik bereik, en daarvoor was 'n algemeen verstaanbare bo-gewestelike taal nodig met so min as moontlik moeilike en vreemde woorde of dialekvorme. ${ }^{2}$ Die eerste gedrukte Nederlandse Bybel was die Delftse Bybel van 1477 (die Ou Testament sonder die Psalms); dit was ook die eerste boek wat in Nederlands gedruk is.

Die Nederlandse Protestante het aanvanklik die Bybelvertalings van Maarten Luther as bronteks geneem. Dit was in Hoogduits, maar daar was ook Nederduitse weergawes. Sy Nuwe Testament het in 1521 verskyn en die Ou Testament in dele tot in 1532. In 1523 het die eerste Nederlandse vertalings van Luther se Nuwe Testament in Antwerpen en Amsterdam die lig gesien. In 1535 het die Antwerpse uitgewer Jacob van Liesveldt 'n vertaling van die hele LutherBybel uitgegee. In 1542 het hy die Luther-Bybel opnuut uitgegee, dié keer met

2 Die historiese gegewens in hierdie en die volgende paragrawe is ontleen aan Conradie 1986, De Vries, Willemyns en Burger 1994, Raidt 1980, Van der Wal 1994, Van Zijl 1992, en Wikipedia, de vrije encyclopedie, maar veral Van der Sijs 2004. 
alle kantaantekeninge van Luther. Maar dit het daartoe gelei dat hy van kettery aangekla en ter dood veroordeel en op 28 November 1545 onthoof is.

Die eerste Gereformeerde Bybelvertaling in Nederlands was die Deux AesBijbel of Armenbijbel van $1562 .{ }^{3}$ Die Ou Testament is gebaseer op 'n vertaling van Luther, maar die Nuwe Testament is uit die bronteks vertaal. Tot en met die verskyning van die Statenbijbel was dit die mees gesaghebbende vertaling.

In 1586 en1594 het die State van Holland vir Marnix van St. Aldegonde, wat in 1580 'n Psalmberyming uitgegee het, gevra om 'n nuwe Bybelvertaling te maak omdat hy Nederlands so deur en deur verstaan het. Hy het die eerste versoek van die hand gewys, maar die tweede aangeneem. Pas nadat hy Genesis vertaal het, is hy egter oorlede.

Die behoefte aan 'n Nederlandse vertaling uit die oorspronklike tale het gegroei. Die owerheid was bekommerd oor die stryd tussen die Gereformeerdes en ander Christene, asook, binne Gereformeerde geledere, dié tussen die Remonstrante en Kontra-Remonstrante. Eenheid sou bevorder kon word deur 'n gesaghebbende vertaling wat nie vir teenstrydige interpretasie deur die opponerende partye vatbaar sou wees nie (Van Zijl 1992:64).

Op die nasionale sinode van Dordrecht is in 1618 besluit dat 'n nuwe vertaling uit die grondtale noodsaaklik is. Slegs sterk aanhangers van die Gereformeerde leer is as vertalers aangewys om te verhoed dat op vrysinnige wyse te werk gegaan word. Aangesien die sinode nie geld gehad het nie, het hy die staat om hulp gevra. Die koste van die tagtigjarige oorlog teen Spanje het aanvanklik daartoe bygedra dat die Staten-generaal (die nasionale regering) nie onmiddellik kon help nie, maar later het die staat die vertaling en uitgee gefinansier en geoutoriseer.

Die opdrag aan Marnix het ook vir die vertalers gegeld: (1) die nuwe Bybel moes 'n getroue vertaling uit die Hebreeuse en Griekse grondtekste wees; (2) die teks moes gestel wees in 'n eenvoudige helder taal; (3) die taal moes suiwer wees en dus so min moontlik leenwoorde bevat. Bowendien moes alles van die bestaande vertalings behou word wat nie in stryd was met die waarheid of die suiwerheid en eie karakter van Nederlands nie.

3 Sy vreemde naam het die Bybel ontleen aan 'n aantekening by Nehemia 3:5. Hier word gepraat oor die wederopbou van Jerusalem, waaraan mense met aansien niks wou bydra nie. Die aantekening lui: 'Deux aes en heeft niet, six cinque en gheeft niet, quater dry die helpen vrij'. In hierdie gesegde kom verwysings na die werp van dobbelstene in 'n dobbelspel voor. Dit gee aan dat die armes (deux aes = een en twee) niks besit, en die rykes (six cinque = ses en vyf) niks gee nie en die middestand (quater dry = vier en drie) wel bereid is om te help. In latere uitgawes is hierdie kanttekening verwyder. Van der Sijs (2004:113-114) wei verder daaroor uit. 
Die vertalers het van 7 Julie tot 19 September 1628 in Leiden vergader om taalkwessies soos die spelling, die woordgeslag, verbuiging, vervoeging en die gebruik van leenwoorde te bespreek. Nadat hul besluite in 1633 hersien is, is dit in die vorm van Resolutiën opgeskryf - in Latyn, wat die voertaal van die sinode was. Die vertalers het mij verkies bo die plat vorm mijn (Hij slaat mijn) en as refleksief die Hoogduitse zich bo die Nederduitse sick of die Hollandse hem/ haar(zelve) (Hij wast hem). Ook het hulle die plegstatige gij vir enkel- en meervoud verkies bo die verouderde oostelike vorm du en die Hollandse spreektaalvorm jij. Dié keuse was die doodsteek vir $d u$ in die standaardtaal. Gij het later uit die standaardtaal in Nederland verdwyn, maar ' $n$ lang tyd deel uitgemaak van die skryftaal. Dit leef voort in vaste formules soos Gij zult niet stelen (Van der Sijs 2004:135). In Suid-Afrika het gij tot in die twintigste eeu deel gebly van die half-Hollandse gebede van sommige Afrikaanstaliges.

Die vertalers het Franse en Latynse leenwoorde vermy behalwe dié wat al burgerreg verkry het. Oor (Neder-)duitse leenwoorde is geen besluit geneem nie. Sulke woorde was vir die puriste nie besmet nie, omdat hulle Duits nie beskou het as 'n vreemde taal nie, maar as 'n suster- of moedertaal. Die Statenbijbel bevat dus baie sulke leenwoorde - wat ook onvermydelik was omdat die sinode opdrag gegee het om soveel moontlik van die bestaande vertalings te behou en nou aan te sluit by die Deux Aes-Bybel. Nederlands en Afrikaans het op dié manier 'n hele aantal "gewone" woorde ryker geword soos afvallig, danksegging, dierbaar, eersteling, hooglied, klaaglied, lushof, nuweling, rigsnoer, slagoffer, vreemdeling, suigeling en nog talle ander (Van der Sijs 2004:140).

Die vertalers het hulle nougeset gehou aan die opdrag om die grondteks getrou te volg. Daarom het die teks baie hebraïsmes en gresismes bevat. 'n Twintigste-eeuse taalkundige, J. Heinsius, het ietwat ongenuanseerd gestel dat die Statenbijbel meer vertaalde Grieks en Hebreeus is as Nederlands (Van der Sijs 2004:136). In die eerste hoofstuk van Genesis kom byvoorbeeld die onnederlandse sin voor: "En God zag het licht, dat het goed was" in plaas van byvoorbeeld: "En God zag dat het licht goed was" (De Vries et al. 1994:84).

Die laaste punt van die opdrag aan die vertalers was dat die taal algemeen verstaanbaar moes wees en dus nie 'n bepaalde dialek moes volg nie, maar 'n bo-gewestelike taal. Vertalers en reviseurs is uit verskillende gebiede van Nederland gekies. Wanneer ' $n$ bepaalde vorm tot net een dialekgebied beperk was, het dit nie plek in die Bybel gekry nie (Van der Wal 1994:222).

Die meeste oorsigte van die geskiedenis van Nederlands vermeld dat die Statenbijbel 'n duidelike suidelike inslag het. Hoewel Nieunederlands gegroei het uit Hollandse dialekte, is betoog dat die skryftaal beïnvloed is deur Protestante wat uit Vlaandere en Brabant padgegee het nadat Spanje Antwerpen in 1585 beset en die suidelike Nederlande herower het. Dié gebiede was vroeër 
kultureel toonaangewend, en die taal van hierdie immigrante het om dié rede 'n duidelike stempel op die vertaling gedruk.

Van der Sijs (2004:136-140) bestry hierdie siening met verwysing na die herkoms van die vertalers asook na die taal self. Suid-Nederlandse vorme kom ook voor in die Deux Aes-vertaling. Die statevertalers kon sulke woorde gekies het omdat hulle reeds tot die Bybeltaal behoort het en dus nie as SuidNederlands aangevoel is nie.

Dit geld ook vir die verkleiningsuitgang $-k e(n)$ in plaas van -tje, soos in "Laat de kinderkens tot Mij komen" (Markus 10:14). Die agtervoegsel -ke( $n)$ word tans nog in die suide gebruik, maar ook in Nederduits en Nedersaksies (Van der Sijs 2004:138). Die ietwat verouderde Afrikaanse woord sagkens kom heel moontlik uit die Statenbijbel. Koning Dawid het gevra: "Handelt mij zachtkens met den jongeling, met Absalom" wat die 1933-vertaling gee as: "Saggies met die jongman, met Absalom" (2 Samuel 18:5). Die bekende Psalm 23:2 lui: "Hij voert mij zachtkens aan zeer stille wateren."

Sommige woorde wat die vertalers gebruik het, berus op 'n keuse vir ' $n$ argaïsme en nie 'n suidelike vorm nie. Dit geld nie alleen die reeds vermelde gij nie, maar ook lang vorme wat eindig op -e, soos Heere. Hierdie keuse is later in die Afrikaanse Bybelvertaling gehandhaaf. Dis moontlik dat sulke woordvorme met die uitgang -e plegtig geklink, en die vertalers hulle daarom behou het, soos Van der Wal (1994:222) suggereer. Hoewel die Afrikaanse vertalers Here oorgeneem het, is sy wisselvorm Heer te vinde in liedere, soos Psalm 48 (in die Totius-beryming): "Die Heer is groot waar Sions top ..."'n Hersiene vertaling van 1846/1847 van die Nederlandsch Bijbelgenootschap was te ingrypend vir die Bybellesers - onder meer omdat Heere daarin in Heerverander is. Dit was volgens baie gelowiges nie in ooreenstemming met die eerbied wat God toekom nie. De Nieuwe Bijbelvertaling (eerste druk 2005) gee volgens die "Leeswizer" die Hebreeuse JHWH weer as Heer.

Die skrywers van 'n moderne geskiedenis van Nederlands (De Vries et al. 1994:82-83) skryf dat die vertalers 'n algemene Nederlands geskep het wat in alle streke verstaanbaar was. Hul taal het Nederlands tot vandag toe deursuur; hul woorde het nie alleen op die kansels opgeklink, of tydens die Skriflesing aan die Gereformeerdes se etenstafel nie, maar orals waar Nederlands gepraat word. Die skrywers meen ten slotte dat geen boek die Nederlandse taal so diepgaande beïnvloed het nie as die Statenbijbel (De Vries et al. 1994:82). Dis waar, maar die Statenbijbel het op die vorige vertalings voortgebou.

$4 \quad$ In die Die Bybel 1933/53-vertaling van 2008 (asook in die Goue Jubileum-uitgawe 1933-1983) word die woord zachtjes gebruik, wat waarskynlik in nuwer uitgawes van die Statenbijbel voorkom. In 'n uitgawe van 1919 wat die skrywer hiervan gebruik het, verskyn nog zachkens. 
Van der Sijs (2004:142) konstateer dat die grootste belang van die Statenbijbel die enorme aantal Bybelse uitdrukkings is wat dit aan die standaardtaal gelewer het. Sy maak melding van goed 'n duisend wat opgeteken is. Die meeste gaan terug op ouer vertalings, maar hulle het danksy die Statenbijbel behoue gebly. Ook die taal van vroeëre generasies Afrikaanstaliges het heelparty uitdrukkings uit die Statenbijbel bevat (Boshoff 1921:125-129). ${ }^{5}$ Sommige daarvan het in die 1933-vertaling behoue gebly (vergelyk 3.1).

In 1635 was die vertaalwerk afgehandel. Dit was in 'n tyd toe 'n kwaai pesepidemie gewoed het wat 20000 Leidenaars die lewe gekos het. Terwyl hulle aan die werk was, kon die vertalers elke dag die begrafnisstoete sien verbytrek (De Vries ea 1994:84). Die drukproses het nog 'n verdere twee jaar geduur. Op 17 September 1637 het die Statenbijbel verskyn. Dit was pragtig uitgegee; die nuutste tipografiese en bindtegnieke is ingespan. Op 'n plegtigheid is ' $n$ spesiaal ingebonde eksemplaar aan die Staten-generaal oorhandig. Die Bybel ontleen sy naam Statenbijbel aan die Acte van authorisatie en approbatie van 29 Julie 1637 wat voor in die Bybel afgedruk is. Die Statenbijbel het hierdeur 'n soort simbool van die jong republiek geword (Van der Sijs 2004:133).

Baie mense was aanvanklik onwillig om afstand te doen van die ander vertalings waarvoor hulle so lief geword het. Maar die aanprysing van die Statenbijbel deur die staat en die aandrang van die predikante het tot gevolg gehad dat dit gou aanvaar is en dat daar selfs 'n Statenbijbel-kultus ontstaan het. Mense was bereid om hoë pryse te betaal. Pare wat gaan trou het, het 'n Statenbijbel as geskenk gekry. Vaders het driemaal per dag huisgodsdiens gehou en elke keer 'n hoofstuk voorgelees. Tussen 1637 en 1651 het 300000 eksemplare verskyn (Van Zijl 1992:69-71). Die bevolking was omstreeks 1630 ongeveer 1,8 miljoen (Van der Sijs 2004:47).

Die staat en kerk het gesorg dat drukfoute uitgeskakel word. Die spelling is mettertyd hersien, en deur die eeue is die taal ook aangepas aan nuwe norme, maar groot veranderings was dit nie. Ná die skeiding tussen kerk en staat in 1796 het veranderings makliker geword. Selfs in die sewentiende eeu was sommige stelwyses waarskynlik al ietwat onnatuurlik vir 'n Nederlandstalige. So staan daar in Lukas 12:55: "Daer zal hitte zijn" in plaas van "Het zal heet woorden" soos in die Deux Aes-vertaling.

5 Daaronder is uitdrukkings soos "billik ontstoke", "toorn", "kasty wie jy liefhet", "jou eersgeboortereg vir 'n pot lensiesop verkoop", "van Noag se sap gedrink" (dronk wees), "die ware Jakob", "vanwaar Gehasie?" "Onwetend sondig nie" is onbybels, maar vind sy oorsprong en verklaring waarskynlik in 'n volkseksegese van tekste soos 1 Tim 1:13 en Hebreërs 5:2. Daar was ook ander uitdrukkings soos "om jou lig nie onder die maatemmer te verberg", of "die hare het jou ten berge gerys". 
Ook in Suid-Afrika is die Statenbijbel intensief gelees, en daar het in die agtiende eeu 'n onafgebroke stroom Bybels uit Nederland gekom. Nie alleen het lidmate dit vir huisgodsdiens gebruik nie, maar die reisiger $\mathrm{H}$. Lichtenstein vertel aan die begin van die negentiende eeu dat mense soms nie ander vermaak gehad het nie as om by 'n tafel te sit en psalms te sing of anders te luister na 'n preek of hoofstukke uit die Bybel wat iemand voorgelees het (Van Zijl 1992:107). Na die tweede Britse besetting van die Kaap in 1806 het die Britse en Buitelandse Bybelgenootskap (BBBG; opgerig in 1804) naas Engelse ook Nederlandse Bybels in Suid-Afrika versprei.

\subsection{S.J. du Toit se Bybelvertalings}

Mettertyd het sommige Afrikaanstaliges moeite gehad om die Statenbijbel goed te begryp, en die Engelse Bybel het hulle nog minder verstaan. Dit het in die 1870erjare gelei tot pleidooie deur Arnoldus Pannevis en C.P. Hoogenhout in De Zuid-Afrikaan om die Bybel in Afrikaans te vertaal. Ná heelwat bespreking het 'n groep Afrikaners onder leiding van ds. S.J. du Toit besluit dat 'n Afrikaanse Bybel nodig is, maar dat die volk eers oortuig moes word dat dit 'n eie taal het. Om dit te doen is die Genootskap van Regte Afrikaanders (GRA) in 1875 gestig. Die strewe na 'n Afrikaanse Bybelvertaling het só tot die eerste georganiseerde taalbeweging gelei. 'n Afrikaanse koerant, Die Afrikaanse Patriot, en boeke is uitgegee. Een daarvan, 'n elementêre taalboek, getitel Eerste beginsels van die Afrikaanse taal, bevat 'n paar spelreëls. Die eerste lui: "Ons skryf nes ons praat."

Hoewel die Bybelvertaling nie 'n prioriteit vir die GRA was nie, het twee lede daarvan met die hulp van hul vriende vertalings van Bybelboeke aangepak. C.P. Hoogenhout het die Markus-evangelie in 1878 vertaal. Dit is egter nie uitgegee nie, maar 'n handskrif daarvan het behoue gebly. In die 1890erjare het S.J. du Toit met die hulp van 'n paar ander die vertaling van die Bybel aangepak, en die vertalings van sewe Bybelboeke is tussen 1893 en 1908 gepubliseer, sommige daarvan in die godsdienstige tydskrif Stemmen des Tijds. Sy eerste vertaling was dié van Genesis in 1893, die tweede dié van Matteus in 1895 (hoewel die naam Matteus in verskeie vertalings verskillend gespel word, word hier deurgaans by Matteus gebly).

In party opsigte was Du Toit die latere vertalers voor - woorde soos veldlelies (Matteus 6:25), pleks van lelies van die veld en veld-heuning (Matteus $3: 4$ ), pleks van wilde heuning is eers weer (met 'n ietwat ander spelling) in die 1983-vertaling opgeneem. Ook met enkele grammatiese konstruksies was Du Toit modern (vergelyk 3.3 en 3.4). Ander vorme en konstruksies doen vandag verouderd aan. ' $n$ Voorbeeld is die infinitief worde (wat in die spreektaal moes geleef het) soos in "en Hy begin bedroef en angstig te worde" (Matteus 26:38). 
'n Sintakties opvallende patroon is die verbinding van die infinitiewe hê, wees en worde met ' $n$ hulpwerkwoord en voltooide deelwoord. In Eerste beginsels word as voorbeelde van die "toekomende tyd" onder meer gegee: "Ek sal geloop hê" en "Ek sou geloop hê" (GRA 1876:21). Tans word het in plaas van hê gebruik. Conradie (1983:10-11) wys daarop dat Du Toit in sy kommentaar gebruik maak van formulerings soos: "di vertaling moes hier so of so gewees hê" en "Daarteen moes Adam en Eva reeds gewaak hê ... as bewakers van die Paradys."

In ooreenstemming met die "Ons skryf nes ons praat"-reël gebruik Du Toit vir (gespel ver) taamlik kwistig; so kom daar gevalle voor soos die volgende (1933-ekwivalent tussen hakies): "Verheug ver julle en wees baing bly" (Verbly en verheug julle); "dat hulle julle goeie werke kan siin, en ver julle Vader wat in die Hémele is, verheerlik" (dat hulle julle goeie werke kan sien, en julle Vader wat in die hemele is, verheerlik) (Matteus 5:12,16); "jou Vader [...] sal dit ver jou vergelde" (sal jou vergelde); "En vergéwe tog ver ons ons skulde" (en vergeef ons ons skulde) (Matteus 6:6, 12).

E.H. Raidt (1980:219) oordeel tereg dat Du Toit "beslis 'n kernagtige, pittige Afrikaans gebruik en ' $n$ fris, selfs digterlike benadering tot die probleem van 'n Bybelvertaling" getoon het.

Maar Du Toit het soms Bolands-dialektiese woorde gebruik, of woorde wat nie gepas het in 'n Bybelse styl nie. Hy vertaal Hooglied 7:6: "Hoe mooi is jy en hoe lifelik, o Liifste, om mé te fry" (aangehaal deur Conradie 1983:2). Nog ' $n$ rede waarom sy vertalings nie aanvaar is nie, was waarskynlik die radikale spelling wat hy in die 1890erjare ingevoer het. 'n GRA-lid, G.R. von Wielligh, sê dat lesers en skrywers teësinnig vir die nuwe spelling was. Die meeste GRA-lede was daarteen (Von Wielligh 1925:91-100). En daarby was Du Toit met spelling en al polities gestigmatiseer omdat hy in die Anglo-Boereoorlog kant gekies het teen die republikeinse Afrikaners.

Baie Afrikaanstaliges was in elk geval gekant teen 'n vertaling. Die Vrystaatse en Kaapse sinodes van die NG Kerk het hulle in 1885 en 1886 onderskeidelik teen 'n Afrikaanse Bybelvertaling uitgespreek, en ook voorstanders van Afrikaans het bedenkings gehad (Scholtz 1980:12). Heel insiggewend beskryf Von Wielligh (1925:46) die houding van party ouer Afrikaanstaliges:

Die oumense was gewoond om hul ou Statebybel, met die dik, swart letters, te lees; dit was immers in die ou dae hul vernaamste leesboek op skool. Baie teen hul sin word die spelling verander in die teenswoordige skryfwyse. Liewers het hulle behou: Ick en Ghy (in plaas van Ik en Gy); van Jesi Christi of in Jesum Christum, Ghy èn zult niet steelen, of dingh, of Eynde der Aerde, ens. as die moderne Nederlandse spelling. Hier is natuurlik sprake van die verafgeleë binnelande alwaar die ou Statebybel die botoon gevoer het. 
Vreemd of "tipies Afrikaans" is hierdie houding nie. 'n Sekere konserwatisme ten opsigte van die taalgebruik van die heilige boeke, godsdienstige liedere, liturgie en selfs kerkname kom voor by alle godsdienste: of dit Hindoes is of Moslems, Rooms-Katolieke of Protestante. In Griekeland het daar in 1903 ernstige onluste uitgebreek toe die Nuwe Testament in die volkstaal (Dhimotiki) vertaal is (Trudgill 1983:115). ${ }^{6}$

Individuele GRA-lede het dikwels op direkte wyse 'n Afrikaanse Bybel bepleit. Hoogenhout het in sy geskiedenis van Josef vir kinders gevra dat hulle altyd sal bid dat die Bybel in Afrikaans vertaal word (Scholtz 1965:191). Ook op subtiele, onregstreekse wyse is 'n Afrikaanse Bybel gepropageer. Naudé (2008) wys daarop dat Du Toit dit gedoen het met sy "historis roman", Di koningin van Skeba (1898). Dit was die eerste roman in Afrikaans en is gretig gelees. Hierdie verhaal is in tyd en ruimte ver verwyder van die Suid-Afrika van Du Toit. Deur gebruik te maak van buitelandse en antieke kulture het Du Toit aangetoon dat dit moontlik is om oor enige onderwerp in Afrikaans te skryf en daarin te vertaal, hoe ver dit ook al verwyderd is van die omgangstaal.

Dit sou wel nog 'n tydjie duur voordat hierdie opvatting ingang sou vind. Volgens die taalstryder en latere Bybelvertaler B.B. Keet is die Statenbijbel vroeg in die twintigste eeu oor die algemeen redelik goed verstaan. Die "jong Turke" moes "hard soek" na voorbeelde wat die noodsaaklikheid van 'n Afrikaanse Bybel kon toon. Hy vertel van die boer van Robertson wat in Jeremia 17:11 gelees het van die "veldhoen" wat eiers vergader, maar hulle nie uitbroei nie. Hy kon nie dink wat 'n veldhoen is nie, en het met sy veldkennis gemeen dis 'n skilpad, want dis die enigste dier wat nie self sy eiers uitbroei nie. As daar gestaan het veldhoender was sy probleme kleiner (Keet 1970a:452). Die 1983-vertaling noem dit 'n fisant.

\subsection{Proefvertaling van 1922}

In die eerste anderhalf dekade van die twintigste eeu het baie taalstryders gemeen dat hulle met 'n Bybelvertaling moes wag omdat Afrikaans "nog in die maak" was, soos een van hulle, ds. Willem Postma, dit gestel het (Nienaber 1934:58).

'n Groot struikelblok vir skrywers was dat daar tot in 1915 nog geen algemeen aanvaarde spelreëls was nie. Vrystaatse en Kaapse koerante het

6 lets van die taalkonserwatisme is selfs waarneembaar in die manier waarop Du Toit die werkwoord bidde (wat destyds plegtiger moes geklink het as bid) gebruik: nie alleen as infinitief nie, maar ook in ander sintaktiese funksies: "En as julle bidde, moet ni wees nes di skynheilige ni; want hulle staan graag en bidde in die Sinagoges, [...] Mar jy, as jy bidde, gaan in jou binnekamer, en sluit jou deur toe, en bidde tot jou Vader ..." (Matteus 6:5-6). 
sommige Afrikaanse woorde verskillend gespel. Ds. Conradie skryf in die voorwoord tot sy Kinderbybel van 1912: "Die spelling van verskeie woorde is nog nie vasgestel nie, en dit het my dikwels byna laat moed opgee. Byvoorbeeld: gelowe, glo of geloof; gedo, gedoë, of gedoog; teunaan, of teenaan ..."

Maar kort daarna was die standaardisering van Afrikaans ver genoeg gevorder dat die Zuid-Afrikaanse Akademie voor Taal, Letteren en Kunst op 18 September 1915 die Afrikaanse spelreëls kon goedkeur. Van 1914 af het 'n paar faktore die Afrikaanse taalbeweging laat veld wen. Een daarvan was die besluit deur die provinsiale rade van Kaapland, die Vrystaat en Transvaal in 1914 om vir die doeleindes van die Moedertaalordonnansie van 1912 Afrikaans te beskou as moedertaal van Afrikaanssprekendes, en nie meer "Hollands" nie. ${ }^{7}$ Omdat Afrikaanstaliges hul skoolopleiding deur medium van Afrikaans sou kon ontvang, sou die Statenbijbel baie gou onverstaanbaar vir 'n nuwe generasie word. Daarop het S.J. du Toit se seun, prof. J.D. du Toit van die Gereformeerde kweekskool op Potchefstroom, die digter Totius, in 1914 in 'n artikel in Het Kerkblad gewys. Dat hy reg geoordeel het, blyk uit die ervaring van 'n ander Bybelvertaler, ds. J.D. Kestell. Hy het vroeg in die 1920erjare van jong mense in Bloemfontein, onder andere studente, verneem dat die Statenbijbel vir hulle onverstaanbaar geraak het en dat hulle maar liewers die Engelse St. James-vertaling lees (Van Schoor 1992:325).

Ook in 1914 het 'n jong NG teoloog, dr. B.B. Keet, in 'n lesing vir 'n Afrikaanse Bybel gepleit. Sy lesing is geplaas in Ons Moedertaal, 'n blad wat die jong taalstryders van Stellenbosch in daardie jaar opgerig het. Blykbaar het ds. Kestell, moderator van die sinode van die Vrystaatse NG Kerk, met die BBBG oor 'n Afrikaanse Bybel gekorrespondeer, want in April 1916 het die Genootskap aan Kestell laat blyk dat hy bereid is om die Bybel op sy koste te laat druk as 'n erkende kerkgenootskap hom dit vra. Kestell het geweet dat die jong ds. N.J. van der Merwe van Wepener sterk oor 'n Afrikaanse vertaling gevoel het, en hom genader (Van Schoor 1992:324). Hy het in Mei 1916 op die Vrystaatse sinode voorgestel dat die Bybel in Afrikaans vertaal word in samewerking die NG Kerke in die ander provinsies, asook die Gereformeerde Kerk en die Nederduitsch Hervormde Kerk van Afrika. Die sinode het dit aanvaar.

Wat die vertaling kon vergemaklik, was die publikasie in 1917 van die eerste uitgawe van die Afrikaanse Woordelijs en Spelreëls. Een van die voordele van die standaardisering was dat taalkundiges reeds oor sommige wisselvorme besluit het, sodat die vertalers dialektiese woordvorme kon vermy.

7 Die ander faktore wat die Afrikaanse beweging bevorder het, was die stigting van die Nasionale Party in 1914, die rebellie van 1914 en gevolglike groei van Afrikanernasionalisme, en die totstandkoming van die Nasionale Pers, wat binne enkele jare die vernaamste uitgewer van Afrikaanse koerante en tydskrifte sou word. 
Afrikaanstaliges spreek byvoorbeeld die woord ook op drie maniere uit: naamlik ook, oek en ok. Du Toit het oek gekies, ook vir sy Bybelvertalings, en geskryf: "n Mens goi oek ni jonge wyn in oue knapsakke ni ..." (Matteus $9: 17)$. Maar oek was glad nie 'n algemene vorm nie. Op 'n taalkongres in die Paarl in 1896 het Du Toit die mense laat stem tussen die wisselvorme van 'n paar woorde; en 19 het vir ook gestem, 35 vir ok en tien vir oek. Die Akademie het die spelling ook gekies. 'n Taalkundige, J.J. Smith, het in De Huisgenoot van April 1917 betoog dis die vorm wat in die Nederlandse skryftaal bestaan en bygevoeg:

Als daar verskillende uitsprake van een en dieselfde woord bestaan, is dit stellig die verstandigste plan om die vorm vir ons skrijftaal te kies, wat die naaste aan die Nederlandse skrijfvorm is (Smith 1917:314).

Soos die Statenbijbel-vertalers het die voor- en eindvertalers, asook die taaladviseurs, uit verskillende dele van die land gekom. Van 1917 af het die taalkundiges T.H. le Roux, D.F. Malherbe en J.J. Smith as taaladviseurs opgetree, later ook S.P.E. Boshoff. Eersgenoemde drie het in die Boland grootgeword, hoewel Malherbe later in Bloemfontein werksaam was, en Le Roux in Pretoria. Boshoff is 'n gebore Vrystater, wat in die Boland skoolgegaan en later in Potchefstroom en Pretoria gewerk het. Die vyf eindvertalers was van die Gereformeerde Kerk. Totius, wat in Potchefstroom gewoon het, maar grootgeword het in die Boland; van die Hervormde Kerk dr. H.C.M. Fourie, deur en deur 'n Transvaler; en van die N.G. Kerk drie: Kestell, 'n Vrystater, wat grootgeword het in Pietermaritzburg; B.B. Keet, afkomstig uit die Oos-Kaap maar lank op Stellenbosch, van 1919 af professor; en E.E. van Rooyen, gebore op Oudtshoorn en van 1919 professor op Stellenbosch. lemand wat groot invloed op die taal uitgeoefen het (Van Schoor 1992: 331; Naudé \& Van Rooyen 2008:9), was L.J. du Plessis van Potchefstroom (later professor en groot figuur in die Afrikanerpolitiek), wat as sekretaris van die Bybelvertalingskommissie opgetree het. Sy eintlike werk was om vyf kopieë van die vertaalde stukke vir die vertalers oor te tik, maar Kestell en Totius het hom benoem as taaladviseur, veral vir die vertaling uit Grieks.

Aanvanklik was daar blykbaar nog te veel verskil van mening om finaal oor sommige kwessies te besluit. Nienaber (1934:81) maak melding van 'n vergadering in 1917 waarop geen definitiewe besluite geneem is nie oor onder meer verskeie woorde en woordvorme, die plek van die tweede nie in ontkenningsinne, die uitgang -e by attributiewe adjektiewe en die keuse van wat of die as betreklike voornaamwoord.

'n Paar vertalers het in 1918 in Kaapstad beraadslaag met taalkenners soos Smith en J.H.H. de Waal. De Waal was die vernaamste ontwerper van die spelsisteem van De Goede Hoop en die Afrikaanse Taalvereniging. Sy standpunt aan die begin van die eeu was, in reaksie op S.J. du Toit se ongewilde 
spelling, dat daar nie onnodig van die Nederlandse spelling afgewyk moes word nie. Die vergadering het in 1918 besluit oor 'n paar woorde waarby die eerste Afrikaanse woordelys ' $n$ keuse toegelaat het. Hulle het besluit om ek te gebruik in plaas van ik (Conradie het hom in sy Kinderbybel by $i k$ gehou), toe pleks van toen, soos pleks van soals, as pleks van als, die besitlike voornaamwoorde my en sy en se pleks van myn en syn en nog 'n paar (Nienaber 1934:82).

Ook oor die spelling van baie is beslis. In verskillende publikasies is veertig spellings daarvan opgeteken. Op die taalkongres van 1896 het baing 42 stemme gekry, en banja 19. S.J. du Toit het baing gebruik. In die eerste uitgawe van die Afrikaanse Woordelijs en Spelreëls is drie vorme erken: baie, baje en baing. Die vertalers het in 1918 besluit om baie naas vee/ te gebruik, en dit het gehelp dat die spelling baie gewen het teen baje en baing. Maar die vertalers het baie soveel gebruik dat prof $\mathrm{J}$. du Plessis van Stellenbosch, wat die evangelies as reviseur nagegaan het, aan ds. Kestell geskryf dat hy die vooroordeel teenoor veel nie kan verstaan nie. Veel staan in die Afrikaanse woordelys, en al het dit nie daar gestaan nie, moes die vertalers dit gebruik het. "Veel vir persone en baie vir dinge en als adverbium, is 'n goeie reël" (aangehaal deur Nienaber 1934:149).

Die proefvertaling, wat in 1922 verskyn het, illustreer die taalkonserwatisme waarna in 2.2 verwys is. Die eerste vertalers het veral moeite gehad met Bybelgedeeltes of uitdrukkings wat die lesers so goed geken het dat dit as't ware deel van hul lewens was. Conradie (1916:362) het dit nie gewaag om die "Onse Vader" vir sy Kinderbybel veel van die Nederlands te laat afwyk nie. Dit lui:

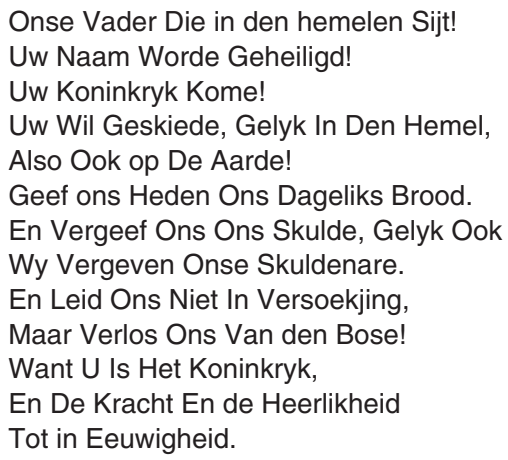

Amen.

Ook in die proefvertaling van 1922 is met die "Onse Vader" so min as moontlik van die Nederlands afgewyk, hoewel dit veel nader aan Afrikaans is as in Conradie se Kinderbybel. Dit lui soos volg in Matteus 5:9-13:

$9 \mathrm{U}$ moet dan so bid: Onse Vader, wat in die hemele is! U Naam worde geheilig. 
$10 \mathrm{U}$ koninkryk kome. $U$ wil geskiede soos in die hemel, so ook op die aarde.

11 Gee ons heden ons daëlikse brood.

12 En vergeef ons onse skulde, soos ons ook vergeef onse skuldenare.

13 En lei ons nie in die versoeking nie, maar verlos ons van die bose. Want Uwe is die koninkryk en die krag en die heerlikheid in der ewigheid, Amen.

'n Uitdrukking wat problematies vir die Afrikaanse Bybel was, is de Zoon des Menschen van die Statenbijbel. Dit is in die 1922-vertaling weergegee as die Soon des mensen. Die vertalers het in 1918 besluit om seun vir zoon te gebruik, "behalwe in verhewe styl en geykte uitdrukkinge Soon Des Mensen, Soon van God" (Nienaber 1934:82). Selfs goeie taalkundiges soos D.F. Malherbe en J.J. Smith het gemeen dat Soon des mensen nie verder verafrikaans moet word nie, maar L.J. du Plessis het Soon des mensen as 'n "taalkundige gedrog" beskou. Die 1933-vertaling het Seun van die mens gebruik en dis in die 1983-uitgawe behou.

Die 1922-proefvertaling is uit die Statenbijbel gemaak, en die titel toon reeds die Nederlandse invloed: Die vier evangelië en die psalme. Mense het beweer die proefvertaling is "nog vis nog vlees", en H.C.M. Fourie het gesê dis "stompstert-Hollands". Die meervoud van fariseër was fariseë (Farizeën) - en Langenhoven het gevra: "Wat is die enkelvoud - fari-meer of fari-oseaan?" (S.J. du Toit het reeds Fariseers gebruik) (Pienaar 1946:390).

Die skerpste kritiek was van Gustav Preller, die man wat in 1905 met die tweede georganiseerde Afrikaanse taalbeweging begin het. Hy het as redakteur in Ons Vaderland (26 November 1926) kommentaar gelewer op die $£ 5000$ wat Die Volksblad vir die vertaling ingesamel het. Preller skryf:
Wat ons self betref het ons ... ons nooit kon warmmaak oor die vertaling van onse Bybel in Afrikaans nie; en wel omdat ons dit sowel as die ver- heffing, tot offisiële landstaal, as in die grond verkeerd beskou, d.w.s. teen die belange van onse taal. Vir ons Afrikaanse taal sou dit na ons beskeie oordeel 'n seën gewees het as ons die Bybel nog 'n halwe eeu lang in die mooie hoog-Hollands kon gelees het.

Hy het gemeen dat die Afrikaanse spelling nog nie algemeen was nie, en dat die vertaling 'n vormleer gaan "yk wat die taal lelik stram en stroef moet maak". Hy het betoog dat Afrikaans nog nie behoorlik gestandaardiseer was nie (Steyn 1987:208).

Sy laaste stelling was ten dele waar. Sommige grammatiese verskynsels was onvas, en Preller self het in die jare twintig nog 'n stryd met die Akademie gevoer om bepaalde vorme erken te kry. Op 'n Akademievergadering in 1927 
het hy en 'n paar ander Transvaalse joernaliste vergeefs geprobeer om aan die Afrikaanse skryftaal 'n meer konserwatiewe karakter te gee (Steyn 1987:215216). Ondanks die negatiewe kommentaar is 70000 eksemplare verkoop, wat toon hoe graag die mense 'n Bybel in Afrikaans wou hê (Pienaar 1946:389).

Ná die skerp kritiek is die vertaalmetode verander en daar is uit die grondtale vertaal, maar steeds met die Statenbijbel rekening gehou. Die eerste proefvertaling is taamlik ingrypend verander en die finale proefvertaling van 1929 met die nuwe titel Die vier Evangelies en die Psalms verskil nie veel van die 1933-vertaling nie (Pienaar 1946:399).

\section{OP PAD NA DIE "SUIWERE VOLKSTAAL"}

Die vertalers het 'n moeilike taak gehad: hulle moes die Bybel in Afrikaans vertaal, maar nie te veel afwyk van die vertroude en geliefde Statenbijbel nie. Kestell het in 1924 aan Totius geskryf hul opdrag was om "die Statenvertaling so naby as moontlik te volg". Hy het bygevoeg: "My opinie is dat ons aan die opdrag moet voldoen, maar altyd in die eerste plaas dink aan die Afrikaanse vorm waarin die oorsetting giet" (Van Schoor 1992:328). Die Bybel moet in die "suiwere volkstaal" kom, het 'n ander vertaler, Keet, later betoog (1951:117). Maar soos hy self ingesien het, het die Statenbijbel so diep in die geheue van die vertalers vasgesit dat hulle moeilik kon afwyk van die vorme wat hulle geken het. Dit geld onder meer die woordorde. Die 1933-vertaling lui byvoorbeeld: "En Jesus was ook genooi, en sy dissipels, na die bruilof" (Johannes 2:2). In die hersiene uitgawe is dit: "Jesus en sy dissipels was ook na die bruilof genooi."

Vervolgens word eers gelet op die woordeskat, en kortliks nagegaan hoe die vertalers die voornaamwoorde en enkele grammatiese verskynsels gehanteer het. Dit word gedoen deur ' $n$ vergelyking met die Du Toit- en die 1922-vertalings. 'n Uitvoerige behandeling is in 'n oorsigtelike artikel soos dié onmoontlik.

\subsection{Woordeskat}

Die eerste sin van die Bybel lui in die Statevertaling: "In den begin schiep God den hemel en de aarde". 'n Mens sou in Afrikaans verwag het: "In die begin het God die hemel en die aarde geskep". Tog staan daar nie geskep nie, maar geskape, ook by S.J. du Toit. "In die begin het God die hemel en die aarde geskape." Die sterk voltooide deelwoord geskape is dus gebruik, en die motivering was dat die besondere werk van die Almagtige die besondere woordvorm regverdig. God het geskape, maar die mens het geskep. Die gevolg was dat party mense gedink het daar bestaan 'n werkwoord skape; prof. Keet het gesê dat baie van sy studente, ook goeie studente, dinge gesê het soos: "God het besluit om die aarde te skape" (Keet 1951:116-117). 
In 1933 was daar nog heelparty sterk voltooide deelwoorde in gebruik (skoolgrammatikaboeke het lyste daarvan bevat), sodat dit nie verwonderlik is om taamlik baie daarvan in die Bybel te vind nie. In Matteus 6:4 is daar, buiten die voltooide deelwoord in 'n substantiviese funksie, selfs 'n infinitief op -e: "Jou vader wat in die verborge sien, Hy sal jou in die openbaar vergelde".

Die 1933-vertaling bevat woorde wat nie meer in die omgangstaal gebruik is nie, soos goedertierenheid. Ponelis (2002:285) gee 'n groot aantal neerlandismes in dié vertaling, waarvan baie so hiperformeel en argaïes is dat daar geen spoor van hulle in die omgangstaal bestaan nie. Van Zyl (1983:39) konstateer:

Ek wil my byna verstout om te sê dat op elke plek in die '33-vertaling waar jy stuit op Afrikaans wat vandag nie meer gangbare Afrikaans is nie, jy die Statevertaling byna letterlik terug vind.

Heel merkwaardig is 'n woord in die Tien Gebooie: "want ek die Here jou God is 'n jaloerse God" (Eksodus 20:5). Die Statenbijbel het "een ijverig God". Daardie ijverig is gebruik in ' $n$ betekenis wat vandag in Nederlands verouderd is, naamlik "naijverig", en die verklarende woordeboek Van Dale gee as betekenis aan: "jaloers" soos in "Ik ben een ijverig God". Die Statenbijbel-betekenis is dus korrek vertaal, maar met 'n woord wat baie Bybellesers gehinder het. In 1983 het dit "eis onverdeelde trou aan My" geword, wat duideliker is.

Die eerste hersieners het die 1933-Afrikaans beskou as nie suiwer genoeg nie. Dit was partykeer ontlenings aan Frans via Nederlands wat hulle gehinder het. In die aangehaalde opmerking van Keet oor die strewe na "die suiwere volkstaal" spreek hy ook die mening uit dat die vertalers alle vreemde woorde moet vermy. Sulke "vreemde woorde" is kaptein en offisier, wat in die 1953-uitgawe hoofman oor honderd en owerste oor duisend word. Ook sou die vertalers sommige uitdrukkings in 'n meer konserwatiewe rigting verander. Die welbekende: "Mooi so, goeie en getroue slaaf" (Matteus 25:21) in die gelykenis van die talente sou word: "Welgedaan, goeie en getroue dienskneg" (Keet 1951:13 en 115). Maar blykbaar is later besluit om dit te hou, want in die 1953-uitgawe verskyn "mooi so" steeds.

Die 1933-vertaling bevat woorde wat latere generasies as beledigend en seksisties ervaar het, soos barbaar en heiden. Naudé toon aan hoe hulle in 1983 gewysig is. Waar 'n mens jou broer seksisties kan opvat, word dit jou bloedverwant of jou mede-Israeliet (Naudé 2004:144). In hoe 'n mate die gevoelswaarde van dié soort woorde deur die eeue verander het, blyk duidelik uit die woorde van Gesang 151:6 in die Nederlandse gesangeboek wat tot 1944 ook in Suid-Afrika gebruik is: "Och! brak die dag ook spoedig aan, / Dat Kaffer, Moor en Indiaan / De knie voor U, o Jezuz bogen!" 
Een van die woordkeuses van die vertalers is later skerp gekritiseer. Dié woord kom voor in Deuteronomium 23 vers 2. Die 1983-vertaling lui: "Niemand wat gebore is uit ontoelaatbare geslagsgemeenskap mag lid van die gemeente word nie." Die Statenbijbel gee dit soos volg weer: "Geen bastaard zal in de vergadering des HEEREN komen." Die 1933-vertalers het dit net so verafrikaans; sedertdien het een betekenisvariant van die woord baster so 'n negatiewe gevoelswaarde gekry dat dit vandag byna ' $n$ taboe-woord is. Vermoedelik was die Statenbijbel-betekenis ' $n$ driekwart eeu gelede meer algemeen bekend as nou. Die Woordeboek van die Afrikaanse Taal gee as eerste betekenis van baster die volgende: "Kind wat nie uit 'n wettige huwelik gebore is nie, onegte kind", en as voorbeeld Deuteronomium 23 vers 2 . Die tweede betekenis van die WAT is dié wat vandag aanstoot gee. Naudé (2005:29-35) verstrek voorbeelde van vertalings wat later gebruik is om apartheid te regverdig.

Een saak in verband met die woordeskat wat soms kommentaar van lesers uitlok, is die gebruik van eufemismes en ander versagtende woorde vir seksuele terme en ander sensitiewe sake. Die bekendste is miskien beken, 'n ontlening aan die Statenbijbel. "En Adam bekende Heva" (Genesis 1:4) het by S.J. du Toit geword: "Toen beken Adam ver Eva" en "En die mens het sy vrou Eva beken" in 1933. Vandag is dié stelwyse vreemd. In 1983 is dit pront: "Die mens het met sy vrou Eva gemeenskap gehad". Teen die gebruik van eufemismes kan daar geen beswaar wees nie. Dit hang saam met die styl: bepaalde woorde is meer gepas in 'n sekere situasie as ander. Mens sal nie van die kansel af woorde kan verwag wat mans om 'n braaivleisvuur sou gebruik nie. En die Bybel word dikwels in die openbaar voorgelees.

In vergelyking met twee moderne Nederlandse vertalings hoef ' $n$ mens die 1933 ers nie oral van oorversigtigheid te beskuldig nie. Dit blyk byvoorbeeld uit die woorde wat Potifar se vrou besig om Josef te probeer verlei. In die Statenbijbel sê sy (in Genesis 39:7)": "Lig bij mij", en dis ook hoe S.J. du Toit dit vertaal: "Lê by my!" In twee moderne Nederlandse Bybels is dit dieselfde: "Kom bij me liggen." ${ }^{8}$ Maar in 1933 is dit stelliger: "Kom hou gemeenskap met my." In 1983 is dit weer iets meer eufemisties: "Kom slaap by my."

'n Eufemisme kán wel sy doel mis en onduidelik of snaaks word. Dit gebeur in Rigters 3:24, waar Ehud vir koning Eglon met sy swaard doodsteek, en sy amptenare naderhand wonder waar hy bly. In die Statenbijbel sê sy knegte: "Zeker, hij bedekt zijne voeten in de verkoelkamer". In 1933 is dit: "Hy is seker besig om sy voete te bedek in die koel kamer", terwyl 1983 dit duideliker verwoord: "die koning is seker besig om hom te ontlas in die koel vertrek". In 'n moderne Nederlandse vertaling: "Hij heeft zich zeker weer afgesonderd

$8 \quad$ Dit is die Groot Nieuws Bijbel. (1983) en De Nieuwe Bijbelvertaling (2004). 
om zijn behoefte te doen," en in die Groot Nieuws-vertaling: "De koning zit vast en zeker op de toilet daarbinnen".

'n Mens kan die Statenbijbel-invloed egter nie geheel en al negatief beoordeel nie. Soos reeds opgemerk, het die Statenbijbel sowel Nederlands as Afrikaans met honderde vaste uitdrukkings en spreekwoorde verryk. Ontlenings aan die Statenbijbel is uitdrukkings soos in sak en as (onder meer Jesaja 58:5), 'n steen des aanstoots (1 Petrus 2:7), in die duister tas (Job 12:25), die inwendige mens (Romeine 7:22); berge versit (1 Korintiers 13:2), 'n boom aan sy vrugte ken (Matteus 12:33), 'n doring in die vlees (2 Korintiers 11:7), die gees is wel gewillig, maar die vlees is swak (Matteus 26:41); 'n vreemdeling in Jerusalem (Lukas 28:18). Sondebok, op twee gedagtes hink, uit die bose is Statenbijbel-ontlenings aan Hebreeus, en jou nie onbetuig laat nie 'n ontlening aan Grieks.

Een vaste uitdrukking, wat in die 1922-proefvertaling opgeneem is, het in 1933 verdwyn. Dit is "ter elfder ure" (Matteus 20:9-10), wat ontleen is aan die gelykenis van die arbeiders wat op verskillende tye in die wingerd gaan werk het. Die gelykenis is in die Statenbijbel gegrond op die Joodse werkdag wat om sesuur die oggend begin het, en die eerste uur genoem is. Die derde uur is dus eintlik nege-uur die oggend. Party arbeiders is op die derde uur van die werkdag gehuur, ander op die sesde, ander op die negende, en ten slotte party op die elfde uur. Toe almal hul loon moes ontvang, het ook dié gekom "die ter elfder ure gehuurd waren". In 1922 lui dit: "En toe hulle kom, die wat ter elfder ure gehuur was, ontvang hulle elkeen een penning." Maar in 1933 het dit weggeval omdat die vertalers 'n ander tydsaanduiding gebruik het. Daar begin die arbeiders om nege-uur, twaalfuur en drie-uur, en ten slotte om vyfuur, en in plaas van dié wat ter elfder ure begin het, staan daar dat dit dié was wat om vyfuur begin het.

\subsection{Die keuse van voornaamwoorde}

Voornaamwoorde is soms by taalstandaardisering en Bybelvertaling 'n netelige probleem. Die sinode het in Dordrecht 'n vermoeiende diskussie daaroor gevoer, en volgens 'n sewentiende-eeuse historikus het talle toehoorders onder mekaar gelag oor die teoloë wat so plegtig en eerbiedig die voor- en nadele van elke voornaamwoord beredeneer het (De Vries et al. 1994:77). Dis toe dat besluit is om Ghy, later gespel Gij, en Uw te gebruik en nie Du, Dyn en Dy nie.

Ook in Afrikaans was daar onenigheid oor $u$. Dit is soms aangevoel as oneie aan Afrikaans en 'n ontlening aan Nederlands. J. du P. Scholtz (1980:67) bevind egter dat $u$ van die begin van die agtiende eeu af in Kaapse geskrifte voorkom, ook van onontwikkelde mense in afgeleë streke. $U$ was van vroeg af as beleefde aanspreekvorm bekend, al is dit selde of ooit in die omgangstaal gebruik. 
Die Afrikaanse lesers van die Statenbijbel was daaraan gewoond dat Christus mense met $u$ of gij aanspreek. Wanneer Hy vir Petrus sê dat hy Hom die nag sal verloën, gebruik Jesus die volgende woorde: "Voorwaar, Ik zeg $\mathrm{u}$, dat gij in dezen zelfden nacht, eer de haan gekraaid zal hebben, Mij driemaal zult verloochenen" (Matteus 26:34). In die 1922-vertaling is Christus se woorde aan Petrus soos volg weergegee: "Voorwaar, ek sê u, dat u in hierdie selfde nag, eer die haan sal gekraai het, My driemaal sal verloën."

In 1923 het die vertalers besluit dat hulle jy, jou en julle konsekwent sou gebruik, en $U$ alleen "vir die Opperwese en wanneer 'n mindere 'n meerdere toespreek" (Nienaber 1934:108). Minstens een van die vertalers, H.C.M. Fourie, was erg beswaard oor die $u$. Hy het in 1928 in 'n lesing in Bloemfontein gesê dat hy "baie gebelgd" gevoel het dat $u$ in plaas van jy gebruik is, "want waarom moet Afrikaans dan anders wees as baie Europese tale waarin die Heer as $j y$ aangespreek word? En kan 'n skepsel van die Heer verwag dat Hy in Sy bevel aan Sy skepsels sal sê, u moet dit of dat nie doen nie?" (Nienaber 1953:90).

In die 1929- en 1933-vertaling is jy en julle gebruik: "Voorwaar, Ek sê vir jou ..." Maar baie mense het niks hiervan gehou nie, en in publikasies is baie briewe daaroor geskryf. Selfs P.J. Nienaber (1934:180-181) het gemeen dat dit een van die punte is waarop kritiek gelewer kan word, omdat mens in Afrikaans $U$ gebruik wanneer 'n groep mense toegespreek word. S.J. du Toit het in sy vertaling van 1895 reeds $j y$ gebruik. Hy vertaal daardie vers: "Jesus sê ver hom: 'Waarlik, Ek sê ver jou, dat jy nog vannag, eer di haan kraai ver My driemaal sal afstaan."”

Nog 'n voornaamwoord-probleem kom uit dieselfde gedeelte waar Petrus antwoord. Die Statenbijbel lui: "En Petrus zeide tot Hem ..." (Matteus 26:35). In die 1922-vertaling is die Nederlandse Hem behou: "Petrus sê vir Hem ..." Die Hem is egter slegs vir die Allerhoogste voorbehou; waar daar na mense verwys is, is wel hom gebruik. (In ouer uitgawes van Die nuwe Halleluja was Hem gerieflike om te rym met ' $\mathrm{n}$-em-woord soos $\mathrm{klem}$.)

Die vertalers het in 1923 besluit dat hulle Hom in plaas van Hem gaan gebruik. Du Toit het, soos die 1933-vertaling, deurgaans Hom: "Petrus sê ver Hom ..."

\subsection{Die verlede tydsvorm van die werkwoord}

Die vorming van die verlede tyd in die skryftaal was 'n kwessie waaroor daar aan die begin van die twintigste eeu geen eenstemmigheid was nie. Conradie (1916:63) het sy Kinderbybel geskryf in 'n taal wat (luidens sy "Woord vooraf")

9 In 1896 het ds. S.J. du Toit die aanwesiges op die Afrikaanse taalkongres 'n adviserende stemming laat hou oor bepaalde spelvorme, en toe het hem net 3 stemme gekry en hom 53 . 
"ons jong mense gemakkelik sal kan lees, al het hulle maar min skoolgegaan." Dit is inderdaad in 'n vlot, gemaklike styl geskryf, en tog het hy selfs in die tweede druk van 1916 af en toe imperfektumvorme gebruik, veral sei vir het gesê: "Een more vroeg ging Moses en Aaron naar Farao en sei: Die Here sal more groot haalstene laat reën ...". Conradie se Kinderbybel is geskryf en vir die eerste keer gedruk terwyl heelparty Afrikaanse skrywers nog geprobeer het om die imperfektum te standaardiseer. Imperfektumvorme het voorgekom in koerante, en dikwels by digters soos Totius en Jan F.E. Celliers, selfs aanvanklik Langenhoven. Laasgenoemde het gesê dat hy dit "in 'n tyd van malligheid" wou herstel (Pienaar 1926; Steyn 1989).

Maar dit was 'n vergeefse poging; die imperfektum kon nie laat herleef word nie. Toe die Akademie op sy jaarvergadering van 1927 die kwessie bespreek, het T.H. le Roux verklaar: "Daar kan vandag geen kwessie meer bestaan oor die onvolmaak verlede tyd nie, dit is uitgemaak." lemand het gevra: "Deur wie?" Le Roux: "Deur die gebruik, deur die taaltradisie" (Steyn 1987:215-216).

S.J. du Toit het net enkele sulke vorme gebruik, soos mog, werd, had en gaf, en die 1922-vertaling het net wis en had. In die 1933-vertaling is had byna oral vervang deur gehad het, en is daar minder gevalle van wis, wat ná verdere hersienings verdwyn het (Conradie 1983:6).

In plaas van die imperfektum is meestal die historiese praesens gebruik; ook Conradie doen dit dikwels in sy Kinderbybel. Maar die historiese praesens gee dikwels aanleiding tot stilistiese lomphede. Dit was ook een van Langenhoven se punte van kritiek op die 1922-proefvertaling. Hy maak melding van "die skreiende onmag om pad te vind, in die verhaaltrant, tussen die onvolmaak verlede tyd en die verlede gebruik van die teenwoordige tyd" (Die Burger, 27 Januarie 1923, in Pienaar 1946:390).

Die oordele oor styl is partykeer subjektief en 'n mens kan moeilik bewys dat die 1933-vertalers met die verlede-tydsvorm altyd beter gevaar het as hul voorgangers. Na die oordeel van sommige is die 1933-vertalings van party gedeeltes ten opsigte van die verlede tyd swakker as Du Toit s'n. In die volgende twee willekeurig gekose passasies (die eerste twee verse van Matteus 5 en 27 onderskeidelik) het die 1933-vertalers volgens die skrywer van dié artikel die beste gevaar:

Du Toit: En toen Hy di grote troppe mense siin, klim Hy di berg op, en nadat Hy gaan sit het, kom syn Leerlingena Hom toe; en Hy open syn mond en leer ver hulle en sê:

In 1922: En toe JESUS die skare sien, klim Hy op 'n berg, en toe Hy gaan sit het, kom Sy disiepels na Hem toe. En Hy open Syn mond en leer hulle en sê: 
1933: En toe Hy die skare sien, het Hy op die berg geklim; en nadat Hy gaan sit het, kom sy disiepels na Hom toe; en Hy het sy mond oopgemaak en hulle geleer en gesê:

Du Toit: En toen dit dag geworde was, hou al die O'erpriisters en di Ouderlinge van di volk same raad teen Jesus om ver Hom dood te maak. En nadat hulle ver Hom vasgebinde het, lei hulle ver Hom weg, en gé ver Hom o'er an Pontius Pilatus, di Gouwerneur.

1922: En toe dit môre geword het, het al die Owerpriesters en die Ouderlinge van die volk, saam raad gehou teen Jesus, dat hulle Hem mag om die lewe bring. En hulle bind Hem en lei Hem weg, en gee Hem oor aan Pontius Pilatus, die stadhouer.

1933: En toe dit dag was, het al die owerpriesters en die ouderlinge van die volk saam raad gehou teen Jesus om Hom dood te maak. En hulle het Hom geboei en weggelei en Hom oorgelewer aan Pontius Pilatus, die goewerneur.

\subsection{Die imperatief}

Normaalweg word die ontkenning van bevelsinne in Afrikaans gevorm met behulp van moet nie. Die ontkenning van "Kom!" of "Skryf die brief!" is "Moenie kom nie!" en "Moenie die brief skryf nie!" (ook soms met klem „Moet nie kom nie!") dus nie: "KKom nie!" of "*kkryf nie die brief nie!" (Selfs met bepalings klink sinne soos "Kom asseblief tog nié!" of "Skryf so 'n brief maar liewers nie!", geforseerd of hiperplegtig.) Waar S.J. du Toit hier die normale Afrikaanse patroon volg, gebruik die 1922-vertaling die Statenbijbel-patroon, terwyl 1933 die twee afwissel. Die Statenbijbel sê in Matteus 6:31 "Daarom, zijt niet bezorgd, zeggende", en Mattheus 6:34: "Zijt dan niet bezorgd tegen den morgen". Du Toit gee dit in ooreenstemming met die hedendaagse gebruik aan as: "Daarom moet ni bekommer wees en sê ni" en "Moet dan ni bekommer wees o'er di dag van morge ni". Die 1922-vertaling laat "moet" in albei gevalle weg: "Daarom wees nie besorg en sê nie" en "Wees dan nie besorg vir môre nie", terwyl 1933 die moet-weglating net in die tweede geval kontinueer: "Daarom moet julle jul nie kwel nie" en "Kwel julle dus nie oor môre nie". In die 1953-hersiening het dit so gebly, wat impliseer dat dit die hersieners nie juis gehinder het nie. Die 1983-vertaling het in albei gevalle moet. "Julle moet julle dus nie bekommer en vra" en "Moet julle dus nie oor môre bekommer nie".

Afrikaans gebruik selfs in positiewe bevelsinne dikwels moet. "Jy moet dit doen!" naas "Doen dit!" By minstens een werkwoord laat moderne Afrikaans geen keuse toe nie, en dis by liefhê. Die Statenbijbel kon sê, soos in Mattheus 5:44: "Hebt uwe vijanden lief". Die 1922-vertalers het nog dapper in daardie voetspoor gevolg: "het u vyande lief", maar die 1933-vertalers het die mo- 
derne patroon gevolg: "Julle moet jul vyande liefhê", soos trouens ook S.J. du Toit: "julle moet julle vyande liif hê".

\subsection{Mutatiewe wees}

Die 1933-vertaling het ontslae geraak van is, was en wees saam met werkwoorde wat na beweging of verandering verwys. Hierdie gebruik het veral by Du Toit voorgekom, en in veel geringer mate in die 1922-proefvertaling. In Matteus 5:17-18 verskyn is by Du Toit op vier plekke waar ons vandag het sou gebruik:

Moet ni denk dat Ek nu gekom is om di Wet en di Profete te ontbinde ni. Ek is ni gekom om te ontbinde ni, mar om te vervul. Want, waarlik! Ek sê ver julle, totdat di Hémel en di aarde verebygegaan is, sal daar van di Wet ni ' $n$ jota of tittel verbygaan ni, totdat dit alles gebeur is (kursivering deur die outeur).

Conradie (1983:10-11) bevind dat wees/is in S.J. du Toit se Genesis- en Matteus-vertalings meermale verskyn saam met werkwoorde soos geworde, gekom, gegaan, gebeur, verminder, opgedroog, verskyn, vertrek en gesterwe. In 1922 is die gelykskakeling van mutatiewe met ander voltooide deelwoorde reeds voltrek, maar enkele gevalle het oorgebly, soos in "Is jy nie met my eens geword vir hierdie penning nie?" (Matteus 20:13) en "dié was tot 'n groot ouderdom gekom" (Lukas 2:36).

\subsection{Adjektiewe}

\subsubsection{Meervoud van gesubstantiveerde adjektiewe}

S.J. du Toit en die makers van die 1922-vertaling het die meervoud van adjektiewe in substantiwiese funksie op dieselfde wyse gespel as die enkelvoud. In "Di preek op di berg" lui dit: "Salig di eenvoudige / treurende / sagsinnige / hongerige en dorstige na di geregtigheid / barmhartige / reine van hart / vredeliwende" wat in 1922 ("Predikasie op die berg") so bly: "Salig is die arme van gees / sagmoedige / barmhartige / reine van hart / vreedsame". (Die interpretasie van treurende ensovoorts as enkelvoud wat na 'n klas verwys, maak egter ook sin.) Dit kom ooreen met die Statenbijbel: "Zalig zijn de armen van geest / de zachtmoedigen / de barmhartigen / de reinen van hart". Die 1933-vertaling vorm die meervoud van sulke substantivies funksionerende adjektiewe meestal deur soos tans 'n -s daarby te voeg: "Salig is die sagmoediges". In die 1953-vertaling is dit nog verder gevoer. Woorde soos getuie, gevangene, bose, melaatse en goddelose, wat nog as enkelvoud en as meervoud kon dien, sou in die hersiene uitgawe in die meervoud ' $n$ - $s$ bykry (Keet 1951:115). 


\subsubsection{Attributiewe adjektiewe}

Raidt, wat ' $n$ indringende studie gemaak het van die geskiedenis van die verbuiging van adjektiewe (Raidt 1968) bevind dat die neiging tot defleksie tot vandag toe in Afrikaans aanwesig is (Raidt 1980:182). In S.J. du Toit se vertalings kom veel meer adjektiewe met die e-uitgang voor as tans, soos in die reeds aangehaalde "jonge wyn in oue knapsakke" (Matteus 9:17) of die opskrif "Di noue Poort en smalle Pad" by Matteus 7:16. In 1922 kom die uitgang voor by adjektiewe waarby dit vandag sou ontbreek, maar ontbreek dit waar dit vandag sou voorkom, soos in boos geslag en kou water. Volgens Conradie (1983:8) is dié twee voorbeelde, asook 'n seker skrifgeleerde en 'n seker skuldheer toe te skryf aan regstreekse invloed van die Statenbijbel. In 1933 is daar naas onreine gees en grote vrees ook onrein hande en groot stem.

\subsection{Refleksief}

Die persoonlike voornaamwoorde hem en haar is in Nederlands oorspronklik as refleksief gebruik, behalwe in die oostelike dialekte waar sich voorgekom het. In die sestiende eeu het die Hoogduitse sich en die Nederduitse sick weswaarts versprei deur die invloed van reformatoriese geskrifte. Daardeur het ' $n$ wisseling ontstaan en later het zich die voorkeurvorm geword (Van der Wal 1994:214). Afrikaans het dus die ouer gebruik behou, maar sommige Afrikaanstaliges gebruik deesdae die neutrale sig om hom of haar te vermy. Dit is interessant dat S.J. du Toit as't ware hierdie moderne neiging vooruitgeloop het, byvoorbeeld wanneer hy skryf: "En Jesus draai sig om" (Matteus 9:19). Die 1933-vertalers het die refleksiefvorme hom en haar gebruik pleks van sig.

Dis te begrype dat daar soms verskil van mening onder die vertalers was. Op die vergaderings is H.C.M. Fourie glo soms uitgelag oor sy benaming Skerpioen-nek in Rigters 1:36 en elders; die ander wou iets anders hê as nek (Nienaber 1934:163). N.P. van Wyk Louw het later na hierdie naam verwys wanneer hy hom positief uitlaat oor die 1933-vertaling. Op nek lewer hy nie kommentaar nie, maar prys die vertalers se gebruik om sulke name te vertaal, terwyl die Statenbijbel die Hebreeus behou het. Maar soveel hoofde soveel sinne: 'n Ou-Testamentikus, A.H. van Zyl (1967:407), merk op dat dié tipies Afrikaanse naam (in Numeri 34:4 en 'n paar ander plekke) tussen 'n hele ry vreemdes "n bietjie snaaks" lyk.

Van Wyk Louw begin sy opstel uit 1951 deur te sê: "In ons Afrikaanse Bybelvertaling besit ons ' $n$ groot stuk literatuur', wat hy dadelik presiseer deur te sê: dis 'n versameling boeke waarin groot stukke literatuur voorkom, omdat daar dele is wat bloot opsommings en historiese besonderhede gee. Hy vergelyk die Statenbijbel met Afrikaans, veral ten opsigte van Job 28. Hy noem die Afrikaans 'n pragtige gedig waarin eers ' $n$ myn, of daarna die mynbedryf, uitgebeeld en dan 
die groot vraag gestel word: ons weet hoe om goud en silwer te kry, maar waar vind ons die wysheid?

In die nuwe vertaling is die glans inderdaad afgevee. Of anders: die teks het geword soos ' $n$ ou skildery waarvan laag na laag vernis weggeneem is totdat dit in sy oorspronklike helderheid glans (Louw 1986:15).

Die 1933-vertaling bevat inderdaad, soos Louw betoog, groot literatuur. Die taal en styl is nie onberispelik nie - dit blyk ook uit die aantekeninge wat Louw op sy erf in Johannesburg onder 'n groot appelkoosboom in sy "werkbybel" gemaak het. Hy het verouderde woorde soos mannin onderstreep, en in Genesis 13:5 had vervang deur gehad het. Sy verbeterings dek die hele Bybel behalwe die boek Job (Steyn 1998:932).

Oor die algemeen word dit as swak styl beskou wanneer 'n skrywer dieselfde woord dikwels moet herhaal, veral kort ná mekaar. Vir die hersiening van 1953 is 'n opruiming gemaak van woorde wat dikwels herhaal is soos vir, sê en kry. Op party plekke is sê vervang deur vra of antwoord, kry deur vind en vir deur aan of tot, of anders is die vir weggelaat (Keet 1951:115 en 1970b:312).

Afrikaanssprekendes het die 1933-vertaling met geweldige geesdrif ontvang. Groot Bybelfeeste is gehou, veral in Bloemfontein. In baie gemeentes is ' $n$ lied gesing wat G.B.A. Gerdener geskryf het. Dit begin met die woorde: "Welkom dierbaar Woord van God", en het in die eerste strofe ook die reëls "Welkom in ons moedertaal / Van die Kaap tot oor die Vaal". Dié lied getuig van 'n evolusie wat in twee dekades in die denke van dié kerkman plaasgevind het. In dieselfde tyd dat die eerste Afrikaanse digbundels verskyn het, is ook die digbundels van drie predikante-digters in Nederlands uitgegee: Zevenjaartjes (1908) van A. Moorrees, Pastoriebloemen (1911) van G.R. Keet en Uit mijn jonkheid (1911) van Gerdener (Botha 1980:184). Al drie het volgens die literator, Elize Botha, blyke gegee van 'n sekere neiging "om hulleself te sien as inluiers van 'n (nuwe) Suid-Afrikaans-Nederlandse, nasionale literatuur". In werklikheid, skryf sy, het hulle nie 'n era van nuwe bloei begin nie, maar 'n tydperk afgesluit (Botha 1980:184). Reeds voor 1933 was Gerdener een van die mense wat bewerkings van Nederlandse gesange gedoen het vir verskeie uitgawes van 'n bundel Hallelujaliedere.

Dié soort ommekeer in die houding teenoor Afrikaans het by baie Afrikaanstaliges plaasgevind. Die 1933-vertaling moes 'n bydrae gelewer het tot die verbreiding van die kennis van Afrikaans as kultuurtaal onder die ouer generasie wat min skoolgegaan het of hul opleiding deur medium van Nederlands of Engels ontvang het. Die grootste tydskrif, Die Huisgenoot, het destyds 'n sirkulasie van tussen 35000 en 40000 gehad, en die grootste Afrikaanse dagblad, Die Burger, een van minder as 10 000. Maar die 1933-Bybel is wyd gelees. Tussen Mei 1933 en Desember 1934 het die BBBG 264875 Bybels 
na Suid-Afrika verskeep. Die genootskap het verklaar dat die verkope van die Afrikaanse Bybel 'n rekord was wat nie maklik oortref sou kon word deur verkope van 'n nuwe uitgawe in 'n nuwe taal nie.

Soos die Statenbijbel 'n mylpaal vir Nederlands was, was die 1933-vertaling dit vir Afrikaans. 'n Letterkundige het dit gesien as die "hoogste triomf' van Afrikaans (Pienaar 1946:408). Dit het so geliefd by baie Afrikaanstaliges gebly dat daar tot in 2008 meer as sewe miljoen eksemplare daarvan gedruk is (teenoor sowat 3 miljoen van die latere vertalings).

\section{BIBLIOGRAFIE}

BIJBEL 2004. De Nieuwe Bijbelvertaling. 's Hertogenbosch: Uitgeverij NBG Heerenveen/ Katholieke Bijbelstichting.

BOSHOFF, S.P.E.

1921. Volk en taal van Suid-Afrika. Kaapstad: De Bussy/HAUM.

Вотна, E.

1980. Oor die Afrikaanse prosa en ander opstelle. Kaapstad: Tafelberg.

ConRadie, C.J.

1983. Afrikaanse Bybelvertaling: 'n taal in wording. Lesing, gelewer op 2 Augustus 1983 aan die RAU as deel van die Biblia 83-viering. 'n Kopie word gehou by die Nasionale Afrikaanse Letterkundige Museum en Navorsingsentrum in Bloemfontein.

1986. Taalgeskiedenis. Pretoria/Kaapstad: Academica.

ConRadie, W.J. 1916. Bybelgeskiedenis vir ons volk. Tweede druk of uitgaaf. Kaapstad: HAUM.

De Vries, J.W., Willemyns, R. \& Burger, P. 1994. Het verhaal van een taal. Negen eeuwen Nederlands. Amsterdam: Prometheus.

Die Bybel in Afrikaans 1953. Die Bybel 1933/53-vertaling. Kaapstad: Bybelgenootskap van Suid-Afrika. 1983. Nuwe vertaling. Goue-Jubileum-Uitgawe 1933-1983. Kaapstad: Bybelgenootskap van Suid-Afrika. 
Die Genootskap van Regte Afrikaanders (GRA) 1876. Eerste beginsels van die Afrikaanse taal. Kaapstad: GRA.

Groot Nieuws BiJBel 1983. Vertaling in omgangstaal. Haarlem: Nederlandsche Bijbelgenootschap.

KeEt, B.B. 1951. Hoe die Nuwe Testament hersien is. Die Huisgenoot, 30 November, pp. 13, 115-117.

1970a. Die Statebybel en die Afrikaanse Bybel. Die Kerkbode, 1 April.

1970b. Bible translation, Afrikaans. SESA 2. Kaapstad: Nasou, SESA.

LouW, N.P. VAN WYK

1986. Versamelde Prosa 2. Kaapstad: Human \& Rousseau.

NAUDÉ, J.A.

2004. Afrikaanse Bybelvertalings "vir Afrika". Die vertalers en hulle kulturele agenda. Acta Theologica 24(1):127-146.

2005. Translation and cultural transformation. The case of the Afrikaans Bible translations. In: E. Hung (ed.), Translation and cultural change: Studies in history, norms and image-projection. John Benjamins Translation Studies Series 61 (Amsterdam: Benjamins), pp. 19-42.

2008. The role of pseudo-translations in early Afrikaans travel writing. A corpus-based translation analysis. Southern African Linguistics and Applied Language Studies 26(1):97-106.

NAUdé, J.A. \& Van RoOyen, M.

2008. Vertalers span saam om Bybel te vertaal. Bylae tot Volksblad, 27 Augustus, p. 9.

Nienaber, P.J.

1934. Die geskiedenis van die Afrikaanse Bybelvertaling. Kaapstad: Nasionale Pers.

1953. Monumentale werk het ywer en opoffering geverg. Die Huisgenoot, 4 September.

PienaAR, E.C.

1926. Taal en poësie van die Tweede Afrikaanse Taalbeweging (derde druk). Kaapstad: Nasionale Pers.

1946. Die triomf van Afrikaans (tweede hersiene druk). Kaapstad: Nasionale Pers.

PONELIS, F.

2002. The language ecology of a new Afrikaans Bible. In: J.A. Naudé \& C.H.J. van der Merwe (eds.), Contemporary translation studies and Bible translation. A South African perspective. Acta Theologica, Supplementum (Bloemfontein: Universiteit van die Vrystaat), pp. 280-289. 
RAIDT, E.H.

1968. Geskiedenis van die byvoeglike verbuiging in Nederlands en Afrikaans. Kaapstad: Nasou.

1980. Afrikaans en sy Europese verlede. Kaapstad: Nasou.

SchOLTZ, J. DU P.

1965. Die Afrikaner en sy taal 1806-1875. Kaapstad: Nasou.

1980. Die wording en ontwikkeling van Afrikaans. Kaapstad: Tafelberg.

SMITH, J.J.

1917. Taalvrae en -antwoorde. De Huisgenoot 1(12), April 1917, pp. 314-315.

STEYN, J.C.

1987. Trouwe Afrikaners. Aspekte van Afrikanernasionalisme en Suid-Afrikaanse taalpolitiek 1875-1938. Kaapstad: Tafelberg.

1989. 'n Paar aantekeninge oor Afrikaanse koerante se grammatiese probleme in die 'owergangstijdperk' tot omstreeks 1917. SA Tydskrif vir Taalkunde 7(1):20-29.

1998. Van Wyk Louw - 'n lewensverhaal. Kaapstad: Tafelberg.

TRUDGILL, $P$.

1983. Sociolinguistics. An introduction to language and society. Harmondsworth: Penguin.

VAN DER SIJS, N.

2004. Taal als mensenwerk. Het ontstaan van het ABN. Den Haag: Sdu Uitgevers.

VAN DER WAL, M.

1994. Geschiedenis van het Nederlands. Utrecht: Het Spectrum.

VAN SchOOR, M.C.E.

1992. John Daniel Kestell. 1854-1941. Bloemfontein: Oorlogsmuseum van die Boererepublieke.

VAN ZIJL, W.J.

[s.a.] ( \pm 1992$)$. Van skeepskis na wakis tot boekrak. s.l.: Lux Verbi.

VAN ZYL, A.H.

1967. Bybelvertaling in teorie en praktyk. Tydskrif vir Geesteswetenskappe 7(2):403413.

1983. Die Ou Testament in eietydse Afrikaans. Buurman September-November:39-41.

Verdam, J. \& Stoet, F.A. (Hersiener)

1923. Uit de geschiedenis der Nederlandsche taal. Zutphen: W.J. Thiem.

Von WIELLIGH, G.R.

1925. Baanbrekerswerk. Pretoria: Van Schaik. 
Steyn

Keywords

Bible translation

Standardisation of Afrikaans

Afrikaans syntax
Die Afrikaans van die Bybelvertaling van 1933

Trefwoorde

Bybelvertaling

Standaardisering van Afrikaans

Afrikaanse sintaksis 